\title{
Relevance of Leptospira in boar and for the development of alternative antimicrobial concepts in boar semen preservation
}

\author{
Kathi Scheinpflug ${ }^{1}$, Sabine Schiller ${ }^{1}$, Helen Jäkel ${ }^{2}$, Martin Schulze ${ }^{3 \dagger}$, Dagmar Waberski $^{2+}$ and Kristin Mühldorfer ${ }^{1 * \dagger}$ (D)
}

\begin{abstract}
Leptospirosis is a zoonotic disease of importance to public health and in livestock productions. It causes significant economic losses in pig breeding farms worldwide. However, actual transmission cycles and disease epidemiology in the pig population remain largely unknown. Despite the fact that the potential risk of venereal transmission of pathogenic Leptospira serovars in pigs has been a topic of discussion since the 1970s, reliable data are still lacking compared to other livestock species. Consequently, antibiotics are added to semen extenders to reduce bacterial contamination including pathogens like Leptospira. In view of the global threat of antimicrobial resistances, the routine use of antibiotics in porcine semen extenders is now under debate. Information about the prevalence of Leptospira infections in boar used for artificial insemination is needed for the development of novel antimicrobial concepts in pig insemination.

This short report provides a summary of the state of knowledge, together with negative results from real-time PCR analyses for the detection of pathogenic Leptospira DNA in boar semen. Molecular analyses were performed on 96 raw and extended samples obtained from normospermic ejaculates of 58 boar housed in six different studs in Germany. In the absence of reliable data, it is important to raise the awareness for a subject that can represent a challenge for pig productions in keeping reproductive health and food safety at high levels. The present molecular results indicate that Leptospira might not be a common threat in boar semen. Conclusive evidence would require results from a systematic serological surveillance of boar, combined with seasonal molecular analyses of semen to identify potential carriers, and assess actual seroprevalences, associated Leptospira serovars and transmission events.
\end{abstract}

Keywords: Antibiotics, Artificial insemination, Leptospires, Leptospirosis, Boar, Venereal diseases

\section{Introduction}

Artificial insemination (AI) has become the most important biotechnology in pig reproduction. It is already used for more than $90 \%$ of sows in breeding farms [1] in order to disseminate favorable genetic traits, while minimizing potential risks for venereal infections [2]. Leptospira are common bacterial pathogens of urogenital tract

* Correspondence: muehldorfer@izw-berlin.de

${ }^{+}$Martin Schulze, Dagmar Waberski and Kristin Mühldorfer contributed equally to this work.

${ }^{1}$ Leibniz Institute for Zoo and Wildlife Research, Alfred-Kowalke-Str. 17, D-10315 Berlin, Germany

Full list of author information is available at the end of the article infections in animals and can persist in the kidneys of infected hosts [3]. They may also persist in the reproductive organs as shown for cattle [4] and pigs $[5,6]$, although associated studies in domestic boar are sparse $[6$, 7]. The possibility, that leptospires could be present in semen and subsequently transmitted by AI, has been investigated by many authors with ambiguous results. Strong evidence has been reported for cattle, small ruminants and horses based on molecular detection of Leptospira DNA in semen samples (e.g., [8-10]). For pigs, however, reliable data are still lacking and 
the actual transmission risk through AI remains unclear [2, 11-13].

Potential transmission routes for porcine Leptospira infections, including venereal transmission and associated studies from the 1960s onwards, have already been summarized and discussed by Bolt in 1990 [14]. More recent studies from Vietnam [15, 16], Brazil [17], Kenya [18] and Germany [19] focused on seroprevalences of sows and potential risk factors in pig husbandry. The authors consistently reported on varying serovardependent but predominantly high Leptospira seroprevalences in sows. Most common Leptospira serovars belong to the serogroups Australis, Icterohaemorrhagiae, Autumnalis and Pomona. Potential sources of infections are infected sows and other domestic animals as well as insufficient prophylactic measures, such as inadequate rodent control, introduction of pig carriers, absence of a quarantine regime and/or vaccination, and deficient hygiene measures. Risk analyses from studies in Vietnam and Brazil showed a potential association of serovars Pomona [15], Icterohaemorrhagiae and Castellonis [17] with the reproduction regime (AI vs. natural mating or both), indicating a higher prevalence in farms that only use AI for breeding. Venereal transmission was already assumed for serovars Bratislava and Pomona as an important route for porcine infections due to their persistence in the genital tract and detection in genital fluids [5-7]. However, an experimental infection of boar with Leptospira Pomona did not result in venereal transmission to sows via natural mating, even though the boar were leptospiruric [20].

As a precaution, antibiotics are routinely added to semen extenders to reduce the general risk of bacterial contamination including pathogenic Leptospira, which is implemented in the Council Directive 90/429/EEC (2012), Annex C, of the European Union. The global increase of antimicrobial resistances, however, demands the development of alternative strategies for semen preservation [21]. Recently, we proposed novel antimicrobial concepts in AI of pigs for removal ([22], Jäkel et al. in revision) or replacement $[23,24]$ of conventional antibiotics. These concepts have shown efficiency against commensal and opportunistic bacteria usually occurring in boar ejaculates. There is debate in AI practice as to whether leptospires need particular attention, as they demand special growth conditions and are not included in microbiological screenings of boar semen for quality control. To answer this question it is important to gain information about the relevance of Leptospira infections in domestic boar used in $\mathrm{AI}$ and the actual transmission risk through semen.

In the present study we investigated the presence of Leptospira DNA in boar semen using a validated realtime PCR analysis with a proven detection range and sensitivity for pathogenic serovars. This molecular approach is a first step to clarify whether Leptospira need to be specifically targeted by future antimicrobial concepts in boar semen preservation.

\section{Materials and methods}

This study was part of a joint research project that aims for the development of a feasible low-temperature storage concept for liquid, antibiotic-free preservation of boar semen [22, 24, 25]. Molecular analyses were performed for the detection of pathogenic Leptospira DNA in 96 semen samples collected in 2018 and 2019 from 58 healthy, mature and fertile boar in Germany. Forty-nine animals originated from five different AI centers (boar stud 1 to 5 ) and nine animals were kept in a university livestock husbandry (boar stud 6; details in Table 1). All boar were routinely used for the production of AI doses with 2 to 5 days of rest between semen collections. They received commercial feed pellets for AI boar and were housed in individual pens $(2 \times 3 \mathrm{~m})$ with straw bedding or sawdust litter, equipped with nipple drinkers according to the European Commission Directive for Pig Welfare. Boar were dewormed twice a year and vaccinated against swine erysipelas and parvovirus. Rodent control was carried out in all AI centers.

The 96 samples consisted of 38 normospermic ejaculates (raw semen), 38 extended semen portions of the same ejaculates, and 20 extended semen portions from other boar (one per boar) where raw semen was not available (Table 1). Semen samples $(n=58)$ were extended in AndroStar ${ }^{\circ}$ Premium (Minitüb, Germany) without antibiotics; processing details are described in Hensel et al. [24] and Jäckel et al. (in revision). Both sample types (raw and extended semen) were included in the analysis to control DNA extractions and PCR results for potential positive and negative dilutionassociated effects on PCR performance and sensitivity, resulting from a high content of lipid-rich sperm cells and host DNA in raw semen as well as from a decrease of pathogen DNA in extended semen, respectively.

DNA was extracted from $300 \mu \mathrm{l}$ per sample, starting with a prewash step, as stated in the Current Protocols in Molecular Biology for "Preparation of genomic DNA from mammalian sperm" [26] and instructions from the DNeasy Blood \& Tissue kit (Qiagen, Germany) for purification of DNA from nails, hair or feathers. A real-time PCR targeting the LipL32 gene was performed by using the well-established protocol, primers and probe from Stoddard et al. [27] for the detection of pathogenic Leptospira and the SsoAdvanced ${ }^{\text {Tw }}$ PCR Supermix (Bio-Rad, Germany). The analysis was carried out using the Stratagene Mx3005P system (Agilent Technology, Germany). DNA from a laboratory strain of Leptospira kirschneri serovar Grippotyphosa was used as positive control, 
Table 1 Characteristics of boar studs and semen samples used for molecular analysis

\begin{tabular}{|c|c|c|c|c|c|c|c|c|}
\hline $\begin{array}{l}\text { Boar } \\
\text { stud }\end{array}$ & $\begin{array}{l}\text { Stud } \\
\text { size }\end{array}$ & $\begin{array}{l}\text { Bedding } \\
\text { type }\end{array}$ & $\begin{array}{l}\text { Replacement } \\
\text { rate of boar }\end{array}$ & $\begin{array}{l}\text { Sampling } \\
\text { time }\end{array}$ & $\begin{array}{l}\text { Sampled boar } \\
\mathrm{n}\end{array}$ & $\begin{array}{l}\text { Age of boar } \\
\text { months }\end{array}$ & $\begin{array}{l}\text { Raw semen } \\
\text { n }\end{array}$ & $\begin{array}{l}\text { Diluted semen } \\
\mathrm{n}\end{array}$ \\
\hline 1 & 290 & sawdust & $55 \%$ & $11 / 2018$ & 10 & $19.9 \pm 3.1$ & none & 10 \\
\hline 2 & 450 & sawdust & $60 \%$ & $12 / 2018$ & 10 & $17.9 \pm 4.4$ & none & 10 \\
\hline 3 & 300 & straw & $50 \%$ & $01 / 2019$ & 9 & $16.9 \pm 4.5$ & 9 & 9 \\
\hline 4 & 100 & straw & $45 \%$ & $02 / 2019$ & 10 & $17.7 \pm 7.9$ & 10 & 10 \\
\hline 5 & 330 & sawdust & $60 \%$ & $03 / 2019$ & 10 & $23.3 \pm 6.4$ & 10 & 10 \\
\hline 6 & 10 & straw & $40 \%$ & $06 / 2018$ & 9 & $36.0 \pm 18.0$ & 9 & 9 \\
\hline
\end{tabular}

Stud size refers to the number of boar kept

Diluted semen originated from ejaculates of the same boar investigated

which was kindly provided by the consultant laboratory for Leptospira of the Federal Institute for Risk Assessment in Berlin, Germany.

\section{Results and discussion}

All 96 semen samples were negative for pathogenic Leptospira DNA in the current real-time PCR analyses, including serovars present in the pig population. Porcine leptospirosis is a largely unknown zoonotic disease of public health and economic importance $[12,19]$. It belongs to the reportable epizootics in Germany. To our knowledge, there is no clear uniform scope of action or implemented quality system in AI centers within the European Union and most probably worldwide for serological tests, a comparable serovar panel and interpretation of results. Thus, the present study stimulates further research in this area. Given that boar are usually kept under strict hygienic measures and only enter a stud after passing quarantine, the risk for the occurrence of Leptospira infections in AI boar seems to be low. The importance of appropriate control measures and dry, temperature controlled housing in boar husbandry is however strengthened by the fact that rodents act as primary reservoirs for pathogenic leptospires and that the bacteria survive well in warm, moist environments. Moreover, subclinically infected boar could bear a potential risk for shedding Leptospira in their semen. In the present study, Leptospira-DNA was absent in semen samples although the boar can be infected. The incorporation of routine serological tests in sanitary guidelines for AI centers could therefore facilitate the replacement of serological positive or suspicious carriers with those of healthy individuals of proven semen quality and fertility [28]. Although practicability and economic impact would need to be considered, these measures would facilitate the omission of Leptospira-specific antibiotics in semen extenders and therefore support the global antimicrobial resistance defense strategy.

\section{Conclusion}

With negative molecular results from this study we want to challenge discussions as to whether boar semen pose a serious risk for the transmission of pathogenic Leptospira. In the absence of reliable data, large scale studies in different countries are encouraged to assess actual seroprevalences in boar and the occurrence of specific Leptospira serovars that should be considered for venereal infections. The knowledge would clearly enhance our understanding of the epidemiology of Leptospira infections in pig productions and largely influence the development of alternative strategies to the currently used conventional antibiotics in semen extenders.

\section{Abbreviations \\ Al: Artificial insemination}

\section{Acknowledgements}

The authors want to thank Minitüb (Tiefenbach, Germany) for providing the extender medium, Nadine Jahn and Anita Retzlaff for their excellent technical assistance, and Dr. Anja Riesenbeck for her assessment and contribution with valuable background information related to the topic.

\section{Authors' contributions}

KS and SS performed the analyses and analysed the data. HJ, MS and DW contributed to the acquisition and processing of semen samples. KS and KM designed the Leptospira study. MS, DW and KM contributed to project conceptualization and acquisition of funding. KM wrote the manuscript. MS and DW critically revised the drafted manuscript. All authors read and approved the final manuscript.

\section{Funding}

This work was supported by the German Association for Bioeconomy Research (FBF e.V.), and funded by the German development agency for agribusiness (Landwirtschaftliche Rentenbank) associated with the German Federal Office for Agriculture and Food (AMIKOS 28-RZ-3.054, 28-RZ-3.053, 28-RZ-3.051). The funding body had no role in study design, collection and processing of samples, analysis and interpretation of data, or writing the manuscript. Open Access funding enabled and organized by Projekt DEAL.

\section{Availability of data and materials}

The dataset generated in the current study is available from the corresponding author on reasonable request.

\section{Ethics approval and consent to participate}

All procedures involving animals were carried out in accordance with guidelines and regulations from the European Commission Directive for Pig Welfare and were approved by the institutional animal welfare committees of the Institute for Reproduction of Farm Animals Schönow and of the University of Veterinary Medicine Hannover (TVO-2019-V-20). 


\section{Consent for publication}

Not applicable.

\section{Competing interests}

The authors declare that they have no competing interests.

\section{Author details}

'Leibniz Institute for Zoo and Wildlife Research, Alfred-Kowalke-Str. 17. D-10315 Berlin, Germany. ${ }^{2}$ Unit for Reproductive Medicine of the Clinics/ Clinic for Pigs and Small Ruminants, University of Veterinary Medicine Hannover, Bünteweg 15, D-30559 Hannover, Germany. Institute for Reproduction of Farm Animals Schönow, Bernauer Allee 10, D-16321 Bernau, Germany.

Received: 6 August 2020 Accepted: 9 September 2020

Published online: 18 November 2020

\section{References}

1. Waberski D, Riesenbeck A, Schulze M, Weitze KF, Johnson L. Application of preserved boar semen for artificial insemination: past, present and future challenges. Theriogenology. 2019:137:2-7.

2. Althouse GC, Rossow K. The potential risk of infectious disease dissemination via artificial insemination in swine. Reprod Domest Anim. 2011;46:64-7.

3. Mitchell D, Robertson A, Corner AH, Boulanger P. Observations on the diagnosis and epidemiology of leptospirosis in swine. Can J Comp Med Vet Sci. 1966:30:211-7.

4. Loureiro AP, Lilenbaum W. Genital bovine leptospirosis: a new look for an old disease. Theriogenology. 2020;141:41-7.

5. Ellis WA, McParland PJ, Bryson DG, McNulty MS. Leptospires in pig urogenital tracts and fetuses. Vet Rec. 1985;117:66-7.

6. Ellis WA, Thiermann AB. Isolation of Leptospira interrogans serovar Bratislava from sows in lowa. Am J Vet Res. 1986;47:1458-80

7. Ellis W, McParland P, Bryson D, Cassells J. Boar as carriers of leptospires of the Australis serogroup on farms with an abortion problem. Vet Rec. 1986; 118:563.

8. Heinemann MB, Garcia JF, Nunes CM, Morais ZM, Gregori F, Cortez A, et al. Detection of leptospires in bovine semen by polymerase chain reaction. Aust Vet J. 1999:77:32-4.

9. Lilenbaum W, Varges R, Brandão FZ, Cortez A, de Souza SO, Brandão PE, et al. Detection of Leptospira spp. in semen and vaginal fluids og goats and sheep by polymerase chain reaction. Theriogenology. 2008;69:837-42.

10. Hamond C, Martins G, Medeiros MA, Lilenbaum W. Presence of leptospiral DNA in semen suggests venereal transmission in horses. J Equine Vet Sci. 2013:33:1157-9.

11. Maes D, Nauwynck H, Rijsselaere T, Mateusen B, Vyt P, de Kruif A, et al. Diseases in swine transmitted by artificial insemination: an overview. Theriogenology. 2008;70:1337-45.

12. Strutzberg-Minder $\mathrm{K}$, Kreienbrock L. Leptospire infections in pigs: epidemiology, diagnostics amd worldwide occurrence. Berl Munch Tierarztl Wschr. 2011;124:345-59.

13. Pereira ACM, Silva Júnior $A$, da Costa EP, Pereira CER. The potential for infectious disease contamination during the artificial insemination procedure in swine. In: Lemma A, editor. Success in artificial insemination. London: IntechOpen; 2013. p. 117-39.

14. Bolt I. Leptospirosis in New Zealand pig herds. New Zealand: Doctoral thesis at Massey University; 1990.

15. Boqvist S, Chau BL, Gunnarsson A, Olsson Engvall E, Vågsholm I, Magnusson U. Animal- and herd-level risk factors for leptospiral seropositivity among sows in the Mekong delta, Vietnam. Prev Vet Med. 2002;53:233-45.

16. Boqvist $\mathrm{S}$, Ho Thi VT, Magnusson U. Annual variations in Leptospira seroprevalence among sows in southern Vietnam. Trop Anim Health Prod. 2005;37:443-9.

17. Valença RMB, Mota RA, Castro V, Anderlini GA, Pinheiro Júnior JW Brandespim DF, et al. Prevalence and risk factors associated with Leptospira spp. infection in technified swine farms in the State of Alagoas, Brazil. Transbound Emerg Dis. 2013;60:79-86 First published 2012.

18. Ngugi JN, Fèvre EM, Mgode GF, Obonyo M, Mhamphi GG, Otieno CA, et al. Seroprevalence and associated risk factors of leptospirosis in slaughter pigs; a neglected public health risk, western Kenya. BMC Vet Res. 2019;15:403.
19. Strutzberg-Minder K, Tschentscher A, Beyerbach M, Homuth M, Kreienbrock L. Passive surveillance of Leptospira infection in swine in Germany. Porcine Health Manag. 2018;4:10

20. Tammemagi L, Simmons GC, McGavin MD, Ludford CG. Experimental Leptospira pomona infection of boar, including studies on transmission of infection by coitus. Old J Agr Sci. 1961;18:231-40.

21. Schulze M, Nitsche-Melkus E, Hensel B, Jung M, Jakop U. Antibiotics and their alternatives in artificial breeding in livestock. Anim Reprod Sci. 2020;23: 106284

22. Waberski D, Luther A-M, Grünther $B$, Jäkel $H$, Henning $H$, Vogel $C$, et al. Sperm function in vitro and fertility after antibiotic-free, hypothermic storage of liquid preseved boar semen. Sci Rep. 2019;9:14748

23. Schulze M, Junkes C, Mueller P, Speck S, Ruediger K, Dathe M, Mueller K Effects of cationic antimicrobial peptides on liquid-preserved boar spermatozoa. PLoS One. 2014;9:e100490.

24. Hensel B, Jakop U, Scheinpflug K, Mühldorfer K, Schröter F, Schäfer J, et al. Low temperature preservation of porcine semen: influence of short antimicrobial lipopeptides on sperm quality and bacterial load. Sci Rep. 2020;10:13225

25. Paschoal AFL, Luther A-M, Jäkel H, Scheinpflug K, Mühldorfer K, Bortolozzo $F P$, et al. Determination of a cooling-rate frame for antibiotic-free preservation of boar semen at $5^{\circ} \mathrm{C}$. PLoS One. 2020:15:e0234339.

26. Weyrich A. Preparation of genomic DNA from mammalian sperm. Curr Protoc Mol Biol. 2012:98:2.13.1-3.

27. Stoddard R, Gee J, Wilkins P, McCaustland K, Hoffmaster A. Detection of pathogenic Leptospira spp. through TagMan polymerase chain reaction targeting the LipL32 gene. Diagn Microbiol Infect Dis. 2009;64:247-55.

28. Lopez Rodriguez A, Van Soom A, Arsenakis I, Maes D. Boar management and semen handling factors affect the quality of boar extended semen. Porcine Health Manag. 2017:3:15

\section{Publisher's Note}

Springer Nature remains neutral with regard to jurisdictional claims in published maps and institutional affiliations.

Ready to submit your research? Choose BMC and benefit from

- fast, convenient online submission

- thorough peer review by experienced researchers in your field

- rapid publication on acceptance

- support for research data, including large and complex data types

- gold Open Access which fosters wider collaboration and increased citations

- maximum visibility for your research: over $100 \mathrm{M}$ website views per year

At BMC, research is always in progress.

Learn more biomedcentral.com/submissions 